\title{
Central Bank of Ecuador, 1927: among Dictatorship, Revolution and Crisis
}

\begin{abstract}
On July $9^{\text {th }}, 1925$, a coup d'état overthrew the Ecuadorian government of the president Gonzalo S. Córdova. The Military Junta chose the new president, Dr. Isidro Ayora, who founded the Central Bank of Ecuador in 1927. The majority of historians emphasize the patriotic spirit of the military forces in order to eliminate the influence of private banks. Nonetheless, there is a less popular view of the process known as the Julian Revolution, which understands the coup d'état, and the foundation of the Central Bank of Ecuador, as the result of struggles between bankers due to controversies around currency emissions.

The arguments behind the Julian Revolution were based on some economic facts. Even though real GDP did not decrease in any year from 1913 to 1927, there was a generalized perception of a critical economy due to the constant fluctuation in prices, the increasing of fiscal deficit, and the reduction of revenues from the trade balance. This article proposes two hypotheses: first, the economic crisis was not an isolated case in Latin America, on the contrary, it was part of a regional trend; second, the economic crisis only affected the urban areas, which account for less than half of the total population.
\end{abstract}

Keywords: Central Bank of Ecuador; Julian Revolution; Dictatorship

Corresponding author: e-mail:cnaranjo@ unach.edu.ec

Received 18 October 2016 - Accepted 13 January 2017

This is an Open Access article distributed under the terms of the Creative Commons Attribution-Non-Commercial-No Derivatives License (http://creativecommons.org/licenses/by-nc-nd/4.0/), which permits non-comercial re-use and distribution, provided the original work is properly cited, and is not altered or transformed in any way. 


\section{Introduction}

On July $9^{\text {th }}, 1925$, a coup d'état overthrew the Ecuadorian government of the president Gonzalo S. Córdova, which was replaced by a Supreme Military Junta. After a year, the Supreme Military Junta chose the new president, Dr. Isidro Ayora, who ruled until 1931 and who founded the Central Bank of Ecuador, after the recommendation of the Kemmerer Mission. The Central Bank of Ecuador was the key point around which a new financial structure was established. The main objective of this new financial structure was the fiscal stability using one specific tool: the golden standard.

Some historians have analyzed profoundly this event in the Ecuadorian history, known as the Revolución Juliana ${ }^{1}$, through two perspectives. The first, the patriotic spirit of the military forces that was needed to close a period in which private banks had the control of the political power and, in turn, returned the power to the people. This perspective emphasizes the economic critical situation in Ecuador as the causes of a political and social instability. The second, a less popular view, which understands the coup d'état, and the foundation of the Central Bank of Ecuador, as the result of the struggles between bankers due to the controversies around currency emissions. This point of view underlines the strong influence of Luis Napoleón Dillon, a private banker from Quito, in the military forces that organized the coup d'état.

This paper has three main objectives. First, to review the arguments behind the two main readings of the Revolución Juliana, are they complementary or are they opposed to each other? Was Ecuador living an economic crisis that justified the arguments behind the revolution? Was Ecuadorian economy an isolated case or was part of a trend in the region?

\footnotetext{
${ }^{1}$ The Revolución Juliana comes from the month in which the coup d'état took place.
} 
Second, to build a historical context to understand the coup d'état, the creation of the Central Bank of Ecuador and the influence of the Kemmerer Mission in the construction of the new financial system. Third, to build a comprehensive economic background of the country, using the main macroeconomic statistics available from 1913 to 1927.

\section{Reconstructing the historical versions of the Revolución Juliana}

On July $9^{\text {th }}, 1925$, a coup d'état finished the Ecuadorian President Gonzalo S. Córdova, who had been elected the previous year. President Córdova was replaced by a Military League that was formed in October of 1924, "when a reduced group of young officials, in the heat of the conversations around the adversities in Ecuador, and the need to do something serious, decided, finally, to confabulate to save the country" (Paz y Miño Cepeda 2002, 15). According to Paz y Miño $(2002,13)$, the Revolution had a patriotic idealism that drove the officials to finish the presidential period of Córdova: "in Ecuador, the military coup d'état of the $9^{\text {th }}$ of July, 1925, known as the Revolución Juliana, came to happen because of the collapse of the Liberal State."

The Military League would organize a Supreme Military Junta, which, in turn, would establish a Provisional Government Junta that should govern the nation through a group of people of provable honorability. There were two Provisional Government Juntas: the first operated from July $20^{\text {th }}, 1925$ to January $9^{\text {th }}, 1926$; the second did from January $10^{\text {th }}, 1926$ to March $31^{\text {st }}$, 1926. On April 1 ${ }^{\text {st }}$, 1926, Isidro Ayora Cueva was chosen as the President of the Republic of Ecuador, his term lasted until August $24^{\text {th }}$, 1931, when he was resigned. Dr. Isidro Ayora Cueva founded the Central Bank of Ecuador after the recommendations of Edwin W. Kemmerer who headed the Kemmerer Mission. The Central Bank of Ecuador was the key 
point around which a new financial structure was established, having as the main objectives to achieve the fiscal stability and the bank system modernization.

Historians, who, in majority, share a common point of view, have analyzed the Revolución Juliana under the scope of a patriotic spirit inside the military forces. This patriotism was needed to close a period when private banks had the control of the political power. This point of view is built around the idea that the military forces wanted to return the power to the people. Nonetheless, there is a less popular view of this event, the one that understands the coup d'état, and the foundation of the Central Bank of Ecuador, as the result of struggles between bankers due to controversies around currency emissions.

The first point of view, the most popular one, underlines some kind of patriotic efforts of the military forces that tried to change the Liberal State instated since 1895, the hegemony of the banks from Guayaquil (the main costal city), and the discrimination of the workers. The military forces were concerned about the economic situation installed in Ecuador produced by the main banks: Banco del Ecuador, Banco Comercial y Agrícola, Banco del Pichincha, Banco del Azuay, Banco de Descuento, Compañía de Crédito Agrícola e Industrial.

The ideas of the revolution were "born on October $25^{\text {th }}, 1924$, when a small group of young officers in the heat of the talks on the misfortunes of Ecuador and the need to do something serious, finally decided to conspiring to save the country" (Paz y Miño Cepeda 2002, 15). In May 1925, the President, Gonzalo Córdova, who was in Guayaquil to get treated of some medical problems, received a telegram from his Minister of Interior, Jaramillo Alvarado, who stated, "[...] real data provides the convincing fact that in May the revolution will explode[...] You are the referee and the head responsible for this moment in history. Save the country, Mr. 
President, from a civil war" (El Día $1925,26^{\text {th }}$ of July). On the $9^{\text {th }}$ of July 1925 , a small group of military, the majority were young officials, overthrew the government.

Pérez Ramírez (2014) provides a tribute to the young official who made the decision of saving the country: they "decided to do something for the homeland imbued with patriotic ideals" $(2014,13)$. Pérez stands out the biographies of eight of the young officials, the only ones who singed the foundation of the Military League: Agustín Patiño Donoso, Virgilio Guerrero Espinosa, José Morán Estrada, Carlos Abarca Montesinos, José Antonio Guerrero Hidalgo, Luis A. Rodríguez Sandoval, Samuel Jarrín Polanco, Manuel Martín Ycaza Valverde.

Paz y Miño $(2002,12)$ affirms that the young officials had their internal motivations which underlined the need to ensure a professional career, a better welfare system, with improvements in remuneration, courses and scholarships. On the 10th of July, 1925, one day after the coup d'état, the main newspaper of Guayaquil, published that "[...] the Army of the Republic, convinced that the sacred interests of the country could not continue under the mercy of a regime, that was in absolute divorce with the national will, made the right decision to topple the government" (El Telégrafo $1925,10^{\text {th }}$ of July) of Gonzalo S. Córdova, elected in 1924.

The revolution had a banker within their supporters: Luis Napoleón Dillon. Before the coup d'état, Dillon "tried to get followers inside the Army to take out of the Cordova's government” (Pérez Ramírez 2014, 46). Dillon was a businessman from Quito who founded a bank called Sociedad de Crédito Internacional in 1922, whose main purpose was to issue currency in the highlands. Dillon was convinced that the coastal financial power established in Guayaquil was dominating the country, "Dillon became the leading and most visible 
northern highland critic of the coast" (Rodríguez 1994, 48). Dillon was part of the first Provisional Government $\mathrm{Junta}^{2}$, and worked as Minister of Finance until January 1926. During the second Provisional Government Junta, Dillon was a member of the first board of the Central Bank of Ecuador.

The participation of Dillon in the Revolución Juliana, his decisions as Minister of Finance, his participation in the Provisional Government Junta, and his presence in the first board of the Central Bank of Ecuador, write a less common known version of the revolution: Dillon becomes the cornerstone of the controversy in this part of the paper. His support to the revolution may not have been in favor of the patriotic spirit that flowed in the air of the young military officials, his participation in the revolution may have had other intentions, which will be explained with the second point of view of the Revolución Juliana.

The second point of view about the Revolución Juliana is less known, and probably less accepted by the historians in Ecuador. This perspective emphasizes the personal intentions of Dillon during his participation in the revolution. Guillermo Arosemena (2002) believes that the revolution was financed and supported by a private banker, Luis Napoleon Dillon. According to the narrative of Arosemena, Dillon was a well-educated person, who was obsessed by the rivalry between the Coast (Guayaquil) and Highlands (Quito).

Dillon was the manager of a local bank in Quito, Sociedad de Crédito Internacional. This credit society was used to fund Dillon's textile company called Fábrica de Tejidos de la Sociedad de Crédito Internacional. In fact, when reviewing the researches of the historians that support the first point of view, there is no mention of its function as a national credit

\footnotetext{
${ }^{2}$ The members of the First Provisional Junta were: Luis Napoleón Dillon, José Rafael Bustamante, Francisco J. Boloña, Francisco Arízaga Luque, Pedro Pablo Garaicoa, Modesto Larrea Jijón, and General Francisco Gómez de la Torre.
} 
institution, the only thing said about it is that: "the Sociedad de Crédito Internacional, in 1921, as a credit institution from Quito, became the banking institution that helped to established the electric municipal power plant in Quito" (Pérez Ramírez 2014, 198).

Before 1925, private banks had the authorization of issuing currency because there was no public institution that could monopolize the monetary emissions. Some banks from Guayaquil became very powerful for three reasons: the governmental needs for loans to cover the fiscal deficits; the ability of issuing currency; and, the commercial movement of the city, the biggest companies, by 1900, had their headquaters in Guayaquil, with

a capital between 1 and 5 million sucres, while in Quito, the most important was of only 200,000. The companies from Guayaquil were 10 times larger than in the capital. It could not be otherwise because $95 \%$ of exports came from the coastal provinces and about $90 \%$ of the total bank deposits. The difference in living standards between Quito and Guayaquil was abysmal in favor of the latter causing resentment among citizens in Quito (Arosemena 2002, 18)

The issuing of currency produced an inflationary trend, which was directly related to the behavior of private banks. The price index, compiled by Linda Alexander Rodríguez (1992, 207) shows, from 1921 to 1925 , an annual averaged inflation of $24 \%$. Nonetheless, Arosemena (2002) points out that, contrary to the opinion that the coastal private banks manipulated the government through the covering of its fiscal needs, "they were victims of the Ecuadorian system and abuse of the power of governments. In the past century, banks from Quito, as Banco Union and Banco de Quito, also made the same mistake of addressing the needs of the State budget, they broke a few years from being founded" (Arosemena 2002, 104).

By 1924, Luis Napoleón Dillon was the president of the Chamber of Commerce in Quito, and he was the manager of Sociedad de Crédito Internaciona. He accused the private banks from 
Guayaquil as the institutions responsible for the critical economic situation of the nation, and made constant public speeches asking for changes. When the Military Junta took control of the government, in July $9^{\text {th }}$, they immediately created the Junta of Government with seven people who would manage the new government. The members of the Junta of Government were: Luis Napoleón Dillon, General Gómez de la Torre, General Moisés Oliva, José Rafael Bustamante, Francisco Arízaga Luque, and, from the Coast, Francisco Boloña y Pedro Pablo Garaicoa.

Rodríguez $(1994,47)$ shares the view that Dillon not only had the northern highland's antipathy toward the Coast, "but his hostility was also fueled by the belief that his financial and political ambitions had been thwarted by Guayaquil bankers, particularly Urvina Jado.” Rodríguez explains that Dillon founded the Sociedad de Crédito Internacional to issue currency in the Highlands, yet, the government blocked his intentions. Urvina Jado, president of the coastal Banco Comercial y Agrícola had informed the Minister of Finance, Alfonso Larrea, of Dillon's intentions. The government prohibited the circulation of currency from

\section{Sociedad de Crédito Internacional.}

Rodríguez (1994) pointed out that Urvina Jado behaved in the same way with a bank from Guayaquil, Banco de Descuento, when its managers tried to circulate bills. Urvina protested to the Minister Larrea who immediately prohibited the bank to circulate new bills. In both instances. Linda Rodríguez considers that Urvina Jado acted to protect the nation's currency. President Córdova offered Dillon another portfolio, which was rejected; Dillon believed that "he deserved to be minister of finance since he was the manager of La Internacional, the country's largest textile factory, and because he was one of the most influential members of the highland business community" (Rodríguez 1994, 48). 
Why did the government listen so attentively to Urvina Jado? Rodríguez (1994) thinks that the reason was because the government owed much money to the Banco Comercial $y$ Agrícola. In this sense, the idea that flowed in the environment of the highlanders that the coastal bankers had the control of the government and, therefore, the political power, strengthened around the most influential people in Quito: businessmen, military officials, politicians, and some tabloids. La Antorcha (1924) and El Abanderado (1924), newspapers from Quito, published a series of articles that tried to prove, with the use of evidence that never was published, that Banco Comercial y Agrícola was forcing the government to sell the Galapagos Islands. The situation infuriated the young military officials that finally decided to overthrow the government of President Córdova.

Victor Emilio Estrada, cited by Arosemena (2002), in a public letter, in 1934, provided of new information to understand the Revolución Juliana. When he was the head of Treasury, he found documents pointing the fact that Dillon had wanted to circulate currency issued by his Sociedad de Crédito Internacional. When Mr. Urbina, the President of Banco Comercial y Agrícola, "knew this inflationary project he informed the government, which prevented $\mathrm{Mr}$. Dillon to circulate currency [...] From the moment Dillon realized that Mr. Urbina and Banco Comercial y Agrícola opposed these emissions [...] he became a sworn enemy of Banco Comercial y Agrícola and its manager, and quickly prepared the revolution which trashed the bank and led its manager to the tomb" (Arosemena 2002, 132).

Estrada's statement places the revolution under a controversial scope: the young officials were encouraged and financed by a banker who tried to get vengeance for the limitations he found when he tried to issue currency from his own bank. The revolution was not the 
"product of inflation or devaluation of the sucre, but of vengeance from the person who wanted to circulate fake currency and got prohibited" (Arosemena 2002, 102).

The researchers that see some value in this point of view consider that the difference between the two perspectives of the revolution comes from a regional fact: the majority of historians are from the Highlands (Rodríguez 1992). In the same path of thought, it seems clear that the main objective of the revolution was to move the economic and political power to Quito, and, in order to establish the headquarters of this renowned power, the Central Bank of Ecuador was founded. The military and people who supported the revolution were "determined to end the financial power of the coastal elite, leaders from the Highlands tried to establish the Central Bank in Quito and destroy the Banco Comercial y Agrícola, the largest and most prominent bank in Guayaquil” (Rodríguez 1992, 156).

The first Junta of Government formed commissions to investigate the behavior of some banks, the main one, Banco Comercial y Agrícola. The results were presented to the new Minister of Finances, Luis N. Dillon, on the $22^{\text {nd }}$ of August 1925, in a report that "came to the conclusion that the bank had illegally circulated currency" (Rodríguez 1992, 157). This conclusion was based on questionable interpretations of what meant to have a legal reserve to back up the emission of currency. Shortly after, Dillon recommended the closure of the bank, after imposing a fine of 2,237,093.33 sucres. As the bank had offices in many cities of the country, Dillon also recommended the replacement of Banco Comercial y Agrícola with the foundation of the Central Bank of Ecuador.

The stories behind the Revolución Juliana and behind the foundation of the Central Bank of Ecuador build some new insights that help to see a clearer picture of this event. To be able to read this event through the first point of view, the Hegelian reading of history (Hegel 2001), 
in which contradictory forces create a new path to understand history, is helpful: the critical economic situation, the regional belief that the Coast manipulated the government decisions, and the idealism of the military forces crashed into one result, the creation of the Central Bank of Ecuador.

To understand the second point of view, it is necessary to frame the reading inside the Foucauldian understanding of how power writes history, "Foucault is an antihistorical historian, one who, in writing history, threatens every canon of the craft" (Poster 1982, 116). This Foucauldian framework is helpful to see that this way of telling the story behind the foundation of the Central Bank of Ecuador threatens the traditional understanding of History in Ecuador because the new elements, that were not told before, break the core vision and the common agreement of how to see the Revolución Juliana. This reading proposes a new conclusion: the foundation of the Central Bank of Ecuador was a product of a regional dispute on the economic and political power of the country, with the help of some military officers, the power was founded, or re founded, in Quito.

To be able to propose a comprehensive understanding of the events, some facts have to be taken into account:

First: the military officials that organized the coup d'état were young which shows a common idealism to feel entitled of the transformation of the nation.

Second: there is no doubt that there was the idea of a regional conflict between the Coast and the Highlands, which was reinforced when the banks from the Coast influenced the governmental decisions.

Third: the most influential civilian in the revolution was Luis Napoleón Dillon, this fact is clear to accept considering that Dillon was elected to be part of the First Provisional 
Government Junta, as a Minister of Finance, and, after that, he was part of the first board of the Central Bank of Ecuador.

Fourth: Banco Comercial y Agrícola was closed, and its reserves were used to fund the Caja Central de Emisión y Amortización that became, after a few months, the Central Bank of Ecuador.

These facts build a more complete reading of the Revolución Juliana. The banks from the Coast had an enormous influence in the decisions of the government; this fact reinforced the regional dispute of power between the Coast and the Highlands. The young military officers probably had genuine motives that put them into the position to believe that they were in charge of turning around the economic situation of the nation. The role of the military officers was largely inflated by the most influential civilian in the Highlands, Luis Napoleón Dillon, whose motives had not only a "patriotic" feeling but, mainly, a revenge feeling which caused his involvement in the Revolution, his participation in the first Junta of Government and in the first board of the Central Bank of Ecuador. There is no certainty that Dillon financed the revolution, but this idea would fit the story with no contradiction. Dillon represents the regional struggles between the Coast and the Highlands, the combination of his influence and the military intervention produced a remarkable output: the political and economic power returned to Quito, this was acquired by closing the most influential bank from Guayaquil and by founding the Central Bank of Ecuador in Quito.

Nonetheless, there are still some arguments that have not yet been valued: the economic arguments used to justify the revolution. The "critical economic situation" that Ecuador was living before the revolution is supported by a simple fact, the increasing cost of living. After presenting the influence of the Kemmerer Mission in the region, the economic arguments that 
justify the abrupt closing of the Presidency of Córdova will be analyzed in the following epigraphs.

\section{The United States influence and the Kemmerer Mission in Latin America}

After 1919, the period of the postwar brought two important changes to the Latin American region: first, the increasing U.S. influence through foreign investment; second, the return to the gold standard. During the years that preceded the foundation of the central banks in Latin America, after the Great War, United States stretched its influence by increasing the investment, a hand to development that the region could not deny to hold.

The increasing American influence in commerce and politics was the result of the European weakness and destruction caused in the Great War. From 1913 to 1929, United States pushed away the British presence in the hemisphere,

in 1913 Britain had estimated \$532 million invested in the five Andean republics, while the United States had a mere \$72 million. Sixteen years later, England's investment had increased by only 14 percent, while those of the United States had risen- according to enthusiasm- by over 1200 percent (Drake 1995, 11)

In the Latin-American countries, the American foreign investment went from an averaged 87 million per country in 1919 to 154.3 million of current dollars (Naranjo 2016). In the same study, we affirmed that, in the Andean countries, the American investment moved from the agricultural sector, during the XIX century, to the oil sector, during the first decades of the XX Century: "in Venezuela, the investment in the oil sector reached a 5 per 100 of annual growing... the investment in the oil sector was important for the Venezuelan exports development during the twenties, as well as for the Peruvian and Colombian" (Naranjo 2016, 82). 
In Argentina the agriculture was the main focus of the external investment, the agricultural and livestock production Index went from 29, in 1900, to 117 in 1929. In other countries, such as Panama, Guatemala and Cuba, the General Electric had the control of the electricity production. Finally, the investment in railroads was top in Mexico and Ecuador: in the case of Mexico, the proximity between United States and the coal and iron ore regions in Mexico helped enhance these investments; in the case of Ecuador, the political decisions of the presidents Gabriel García Moreno and General Eloy Alfaro enhanced the American investment in railways. The investment came to the country also as credits, "in the 1920s, there was a boom of foreign private loans from the United States. Sellers managed to put loans to unwary governments" (Thorp 1992, 53), encouraging them to borrow beyond their possibilities.

Figure 1 shows the American investment in some countries in Latin America. From 1919 to 1929, the amount invested raises considerably in all countries, except in Colombia and Peru. The most impressive case was Argentina, where the American investment grew from 0.3 to 28.1 million-dollars/per capita. The American influence in the region increased through the multiplications of investors that reach the needing countries, these investors were dressed with the image of American banks: in 1926, there were 61 branches of US banks in Latin America (Phelps 1927). Table 1 shows the commercial relationship between the United States and the countries of Latin America: from 1913 to 1927, the relationship of commerce dependence remained high with Central American, while it increased with South America. 
Figure 1. American foreign investment/per capita in Latin America, 1919, 1924, 1929. millions of current dollars

Argentina

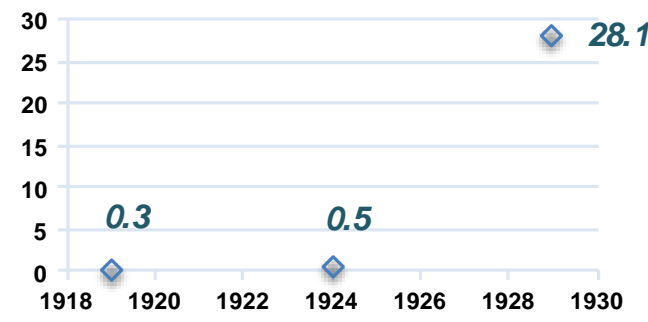

Bolivia

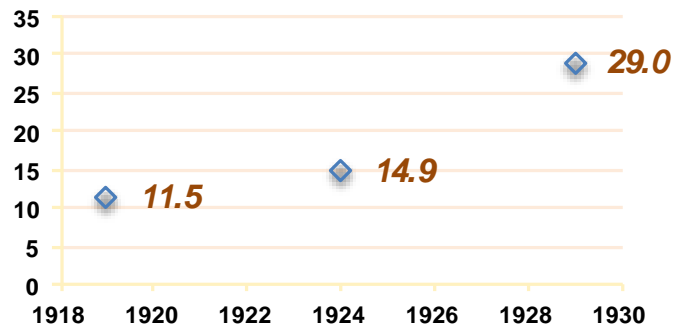

Colombia

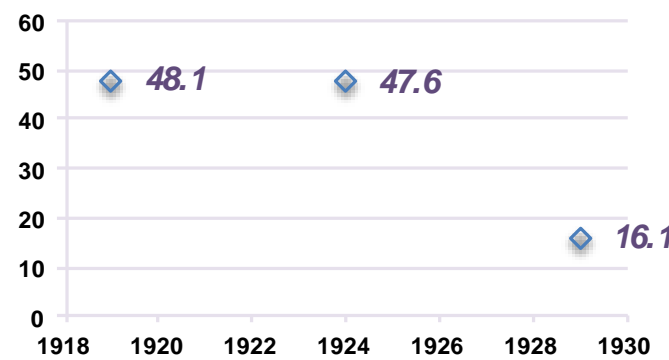

Paraguay

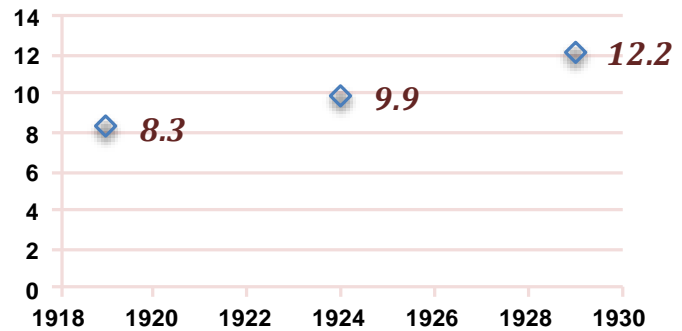

Brazil

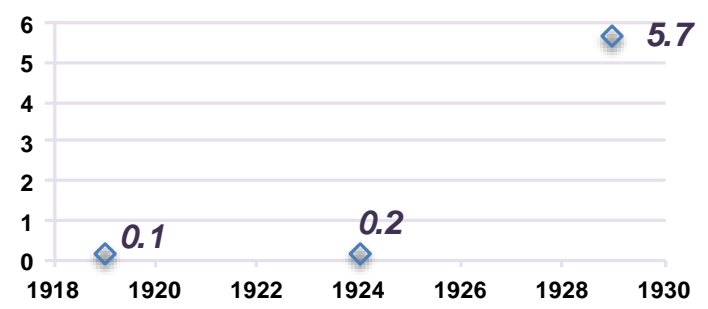

Chile

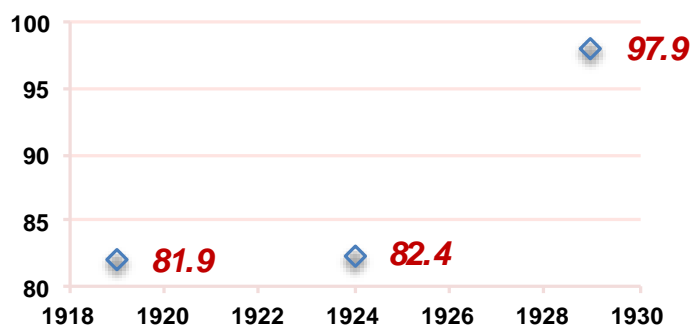

Ecuador

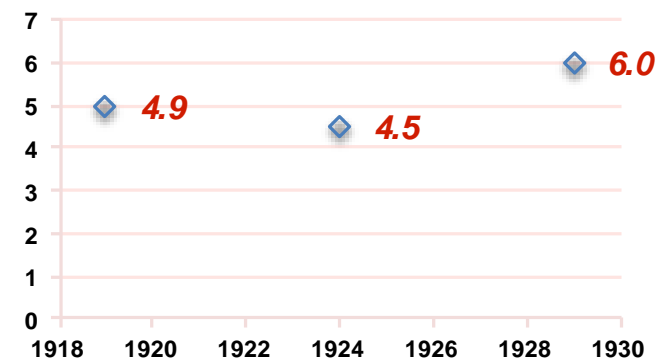

Peru

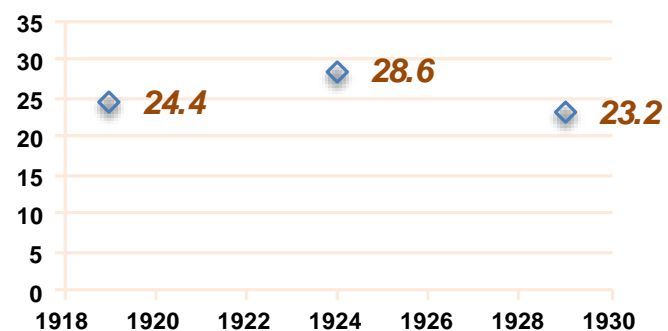

Source: Author's creation. Data for U.S. foreign investment and population come from MoxLad 2016

Online ISSN: 2385-7137

http://revistes.ub.edu/index.php/JESB
COPE Committee on Publication Ethics Creative Commons License 4.0@Creative 
Table 1. Commerce between the United States and Latin America, percentage of the total Latin American commerce, 1913, 1918, 1927

1913

1918

1927

\begin{tabular}{lccc}
\hline $\begin{array}{l}\text { South America } \\
\text { Imports from the U.S. }\end{array}$ & 16.2 & 25.9 & 26.8 \\
Exports to the U.S. & 16.8 & 34.8 & 25.2 \\
Mexico, Central America, Caribe & & & \\
Imports from the U.S. & 53.2 & 75.0 & 62.9 \\
Exports to the U.S. & 71.3 & 73.4 & 58.4
\end{tabular}

Source: Thorp 1992, 53

The return to the gold standard came along with the creation of central banks in the region. This was the product of the influence of the Kemmerer Mission. Edwin Walter Kemmerer was born in Scranton, Pennsylvania, the $29^{\text {th }}$ June 1875 . His father, Lorenzo Dow Kemmerer, had a German ancestry. E.W. Kemmerer attended Wesleyan in Middletown, Connecticut; after obtaining his bachelor, he was accepted for graduate studies on economics at Cornell University. In 1903, Kemmerer obtained a Ph.D. in Economics and Finances; in the same year, he started working as financial advisor to the US-Philippines Commission. Kemmerer helped to establish certain type of measures to support the gold standard in the Philippines. After this, Kemmerer helped, playing a small role, setting up the Federal Reserve System.

Before becoming the "Money Doctor", E. W. Kemmerer worked at Princeton University teaching Money and Banking, and International Finance. During his time at Princeton, his career developed greatly, his main contribution was the book "Modern Currency Reforms" published in 1916, where he cultivated the idea that "adopting a gold standard was the wisest course of action for a nation enjoyed well night universal respect" (Kemmerer 1993, 22). Many nations around the world agree with Kemmerer statements, in fact, by 1930, more than 
40 nations had returned to the gold standard, a system that would prevent the causes of inflation.

In 1917, Kemmerer worked as advisor in Mexico helping to solve the central-banking problems, and in 1919 in Guatemala. In 1918, his book, "The ABC of the Federal Reserve System" (Kemmerer 1922) was published, and through it, his fame as an expert on Central Banks and Federal Reserves was spread around many countries. After visiting Mexico and Guatemala, Kemmerer was hired as financial advisor in Colombia, Chile, Ecuador, Bolivia and Peru, "during his teaching career, Edwin Kemmerer, a professor of economics at Princeton, was called upon to advise the governments of fourteen nations on their monetary standards and policies of fiscal reform and modernization" (Kemmerer 1993, 9).

The advice and policies of the Kemmerer Mission had similar patterns in each country they visited. The common elements in all the countries were: the creation of central banks, Superintendence of Banks, General Comptroller; and the proposal of a series of laws by which the government would settle the gold standard as public monetary policy. These changes in the region did not come out of domestic matters; "it is unlikely that one country's local problems explain its creation of a central bank when all its neighbors were establishing exactly the same institution at precisely the same time" (Drake 1995, 2). The creation of central banks came along with the creation of some public institutions that will structure the functioning of the gold standard. From 1919 to 1930, these structural changes occurred in the countries mentioned above. Table 2 displays the works of the Kemmerer Mission in a chronological order: 
Table 2. Founded institution and approved laws: the results of the Kemmerer Mission in Latin America

Country

Guatemala (1919)

Colombia

(1923)
Founded institutions

- Banco Central de Guatemala
- Banco de la República de Colombia $^{3}$

- Contraloría General de la República de Colombia
Approved laws

- Ley Monetaria de la República de Guatemala

- Ley del Banco de la República

- Ley sobre Establecimientos Bancarios

- Ley de Timbre (it reorganized the operation of Customs and established the Collection of National Revenues)

- Ley de impuesto sobre la renta

- Ley de Contraloría (Transformed the former Court of Accounts into the Comptroller General of the Republic).

- Ley sobre fuerza restrictiva del presupuesto (it limited the powers of the Parliament to organize public expenditure and left this initiative in the hands of the Executive Branch).

- Ley que fijó el número y nomenclaturas de los ministerios.

- Ley sobre títulos negociables

- Ley del Banco Central de Chile

- Ley General de Bancos

- Ley Monetaria

Chile $\quad$ - Banco Central de Chile

- Contraloría General de República de Chile

la - Ley Orgánica de Presupuesto

- Ley de la Contraloría General de la República

- Ley Orgánica del Banco Central del Ecuador

- Banco Central del Ecuador

Ecuador - Superintendencia de Bancos del

(1926) Ecuador

- Contraloría General de la República del Ecuador

- Ley Orgánica de Bancos

- Ley Orgánica del Banco Hipotecario

- Ley de Impuestos Internos.

- Ley de Monedas

- Ley sobre los contratos de prenda agrícola

- Ley de Aduanas

- Ley de Reorganización del Banco de la Nación Boliviana

- Superintendencia de Bancos

- Contraloría General de la - Ley General de Bancos. República de Bolivia • Ley Monetaria

- Banco Central de Reserva del - Ley del Banco Central de Reserva del Perú

Peru Perú.

(1930) - Superintendencia de Banca del Perú

- Ley de Bancos del Perú

- Ley Monetaria

Source: Gozzi and Tappatá 2010, 2.

\footnotetext{
3 According to Santos Molano (2005) the Congress resolved, by a Law of 1922, to create the Bank of the Republic and to empower the government to bring a Mission of foreign technicians.
} 
The first central banks in Latin America were designed for three objectives: first, to preserve the monetary stability; second, to preserve the stability of the banks; finally, to limit the public financing (Jácome 2015). The main tool that these objectives had was the emission of a currency under the gold standard system: in theory, this would produce low inflation rates because it limits the money supply. By 1926, "the gold standard was already established in twelve republics from Central and South America" (Thorp 1992, 65).

The Kemmerer Mission represented the ideals of the U.S. Federal Reserve on how a country should manage its finances and what monetary instruments were necessary to use in order to obtain a balanced budget while controlling the inflation rates. These ideals were spread in the region through the Kemmerer Mission; through the economic branches that were being multiplied in the banking system; and also through different U.S. industries and investments, the more important were: railroads, mining, and electricity. The creation of the Central Bank of Ecuador, and the establishment of the gold standard, as the main monetary policy, was not an isolated policy, quite the opposite, was part of a regional trend that was to be broken when the Great Depression hit the region. ${ }^{4}$

\section{The Kemmerer Mission and the Central Bank of Ecuador}

In 1925, the economy of the nation was critical, some bankers from Guayaquil urged President Córdova to invite Edwin Kemmerer to advice the government in the foundation of a central bank and the stabilization of the fiscal structure, private "bankers thought that the services of a distinguished foreign expert were so vital that they offered to pay the cost of an

\footnotetext{
${ }^{4}$ When the Great Depression started, the Latin American republics decided to leave the gold standard. This happened in different years: Argentina, Uruguay and Brazil in 1929; Venezuela in 1930; Mexico, Chile and Bolivia in 1931; Colombia, Nicaragua, Costa Rica, Peru and Ecuador in 1932.
} 
advisory mission if the government had no money" (Rodríguez 1992, 158). The president Córdova invited Kemmerer before his government was overthrown.

Before the arrival of the mission, Luis Napoleón Dillon opposed the advice of a foreigner, this position was accepted by the Military Junta. Dillon advised the Military Junta to fund the Central Bank of Ecuador using the reserves of the private banks that emitted currency. The payment to the private banks for their reserves in gold would have been less than half of the value. This proposal was detained because of the public tension from the Coast: the pressure was so strong against these intentions that the Military Junta felt obliged to replace the government.

On April $1^{\text {st }} 1926$, the Military Junta chose the Minister of Social Welfare, Dr. Isidro Ayora, as the President of the Republic. In his first decree, Dr. Ayora declared himself as the Supreme Commander of the Nation, his appointment was well received by the public: "Dr. Ayora has proved that the time in charge of the Ministry, and Chairman of the Municipal Council of Quito, are the pearls that adorned his personality" (Coral 1995, 125).

The new President ordered the closure of several banks and imprisoned the managers arguing that they did not obey the order of collecting the illegal checks in circulation. The new government appointed Humberto Albornoz as the new Minister of Finances. Albornoz had the intention of reopening the Banco Comercial y Agrícola to give tranquility to the markets that were anxious because of rumors on other banks being closed. President Ayora rejected Albornoz intentions; the most prominent bank from Guayaquil was never reopened.

In June 1926, the government froze the metallic reserves of the banks that emitted currency, and founded the Caja Central de Emisión y Amortización. This institution represented a transition stage to the creation of the Central Bank. The reserves in gold from these banks 
were transferred to the new institution paying less than half of its value in the market: Dillon's advice was followed at last. In total, the reserves transferred to Caja Central de Emisión y Amortización amounted 10,604,314.75 sucres (table 3), 35 percent came from Banco Comercial y Agrícola.

Table 3. Gold reserves transferred to Caja Central de Emisión y Amortización, in sucres, 1926

\begin{tabular}{lcccc}
\hline \multicolumn{1}{c}{ Bank } & Headquarters & $\begin{array}{c}\text { Year of } \\
\text { foundation }\end{array}$ & $\begin{array}{c}\text { Quantity in } \\
\text { Gold }\end{array}$ & $\begin{array}{c}\text { Percentage of the } \\
\text { Total (\%) }\end{array}$ \\
\hline Banco del Ecuador & Guayaquil & 1868 & $2,572,883.70$ & 24.00 \\
Banco Comercial y Agrícola & Guayaquil & 1894 & $3,716,174.05$ & 35.00 \\
Banco del Pichincha & Quito & 1906 & $2,901,507.00$ & 27.00 \\
Banco del Azuay & Cuenca & 1913 & $737,750.00$ & 0.07 \\
Banco de Descuento & Guayaquil & 1920 & $330,000.00$ & 0.03 \\
$\begin{array}{l}\text { Compañía de Crédito Agrícola } \\
\text { e Industrial }\end{array}$ & Quito & 1908 & $346,000.00$ & 0.03 \\
\hline
\end{tabular}

Total

$10,604,314.75$

100

Source: Author's creation based on the Executive Decree N. 476, 1926.

The government of the President Ayora emitted an executive decree regarding the reserves of the Banco Comercial y Agrícola that were to be transferred to the Caja Central de Emision y Amortizacón. In the executive decree, published in the official gazette on the $9^{\text {th }}$ of November 1926, the government settles the amount and the way to pay the bank for its reserves, it is written that "the Government may order that any dividends paid continue to be on deposits until the purchase by agreement or the immediate withdrawal of circulation of paper money according to the amounts paid, all paper money will be incinerated." This procedure was alike with all the banks whose reserves were transferred. In total, few more than 24 million sucres were incinerated from 1927 to 1929. 
Table 4. Incinerated Currency from Private Banks`Emission, in sucres, 1927-1929

\begin{tabular}{lccccccc}
\hline $\begin{array}{c}\text { Comercial y } \\
\text { Agrícola }\end{array}$ & Ecuador & Pichincha & Azuay & Descuento & $\begin{array}{c}\text { Cía. de } \\
\text { Crédito }\end{array}$ & Caja Central & Total \\
\hline $13,534,000$ & $3,283,655$ & $3,038,400$ & 518,300 & 389,000 & 305,200 & $3,066,000$ & $\mathbf{2 4 , 1 3 4 , 5 5 5}$ \\
\hline
\end{tabular}

The $18^{\text {th }}$ of October 1926, Edwin Kemmerer in his mission arrived to Ecuador invited by the new President of the Republic, Dr. Isidro Ayora. Kemmerer was a well recognized in the United States and in several Latin American countries. ${ }^{5}$ In the case of Ecuador, the reforms were going to be similar as in other countries, nonetheless, there is no evidence that could suggest that Kemmerer was in favor of closing and transferring the reserves of some private banks for the creation of the Central Bank of Ecuador. Moreover, there is no evidence that could suggest that Kemmerer advised the Ecuadorian government on the way the Central Bank had to be founded. That procedure seems to be a local political decision.

Once the Kemmerer Mission arrived in Ecuador, his fame had spread widely; national newspapers published his speeches in Ecuador, Latin America, and the United States. The Ecuadorian press published constantly the benefits and results of the Mission in other countries of the region,

it is evident the advantages that came along the creation of the Central Bank in Chile, previously authorized by Prof. Dr. Kemmerer. The general conditions of Chile when the Central Bank was created were nothing favorable because the country had just emerged from a period of two years of revolutionary governments and was going through a period of a real crisis. (El Comercio, 1927)

During its time in Ecuador, the Kemmerer Mission arrived to some conclusions on the fiscal structure:

\footnotetext{
${ }^{5}$ For more information on each country: Guatemala (Molina Calderon 2007); Colombia (Santos Molano 2005); Chile (Carrasco 2009); Ecuador (Drake 1995); Bolivia (Administration of Studies and Standards 2007); and Peru (Basadre Grohmann 2010)
} 
First, small incomes derived from direct taxes, seven percent from the total income.

Second, great uncertainty on the amount of incomes derived from customs.

Third, limitations and failures in tax collection.

Thus, the Mission proposed not to increase the number of taxes but to develop a more appropriate tax collection procedure. This was going to be achieved through changes made in the Ley Orgánica de Hacienda (Treasury Law). The changes in the tax collection procedure increased the government income in almost 40 percent from 1926 to 1928 , passing from 44 to 61 million of current sucres, the biggest increases came from customs and income taxes (Almeida 1994, 67).

Another important contribution from the Mission was the proposal of a law that would rearrange the banking system in the country. The banking had few regulations that control the behavior of the banks, which emitted currency, but there was a whole in the legislation for the rest of the banking. The new law, called Ley General de Bancos, was proposed to fix the lack of regulation and guide the loans. This law proposed the division of the banking in three: savings; commercial; and mortgage. Moreover, this law would establish the obligation of adopting strict accounting procedures and the publishing of the finances of the banks. It regulated the proceeding of branch offices, international banks and the duration of the banks bestowal (Registro Oficial No. 432, 1927).

The economic policies of Kemmerer Mission were based on two pillars: the adoption of the gold standard and the creation of a central bank. The main purpose of the economic policies of the Kemmerer Mission was the monetary and fiscal stability. For that purpose, Dr. Kemmerer and his team proposed the creation of three institutions and the adoption of seven legal bodies. The Central Bank of Ecuador had four main objectives: emission and conversion 
of currency; stabilization of international exchange; regularization of discount rates; to help banks in times of emergency (Almeida 1994, 84). The bank was managed by a board of eight people, the first members were: Neptalí Bonifaz, Federico Malo, Dr. Clemente Ponce, Luis Alberto Carbo, Enrique Cueva, Luis Napoleón Dillon, Luis Adriano Dillon, and Agustin Rendón.

Kemmerer left the country in March 1927; in the same month, the government promulgated the executive decree to establish of the gold standard. To begin the monetary system under the gold standard, the government decided to settle the exchange rate at five sucres for each U.S. Dollar. Moreover, the gold standard, founded in Ecuador, required a gold reserve of 50 percent of the total deposits and currency in circulation; these reserves could be "in the Central Bank facilities or in recognized banks in New York or London” (Morillo 1996, 37).

After Kemmerer's departure, the Caja Central de Emisión y Amortización became the Central Bank of Ecuador on $10^{\text {th }}$ of August 1927. The Central Bank of Ecuador started with a legal reserve of $27,084,667$ sucres, which promptly increased to $42,891,098$ sucres by the $31^{\text {st }}$ of December 1927 (table 5). The increase of 7,787,756 sucres came from the excessive purchases over sales orders from abroad; the increase of 18,675 in coins of gold came through the convertibility of banknotes to gold; moreover, the Central Bank of Ecuador bought from the government 1,600,000 dollars to a given exchange rate of five sucres per dollar. From the total amount of reserves in gold, 10,604,314.75, value in sucres, came from the private banks whose reserves were transferred to Caja Central de Emisión y Amortización, that represents around 37 percent of total amount in reserves by the $10^{\text {th }}$ of August 1927. 
Table 5. Central Bank Legal Reserve, 1927

\begin{tabular}{|c|c|}
\hline Legal Reserve & Sucres \\
\hline On the $10^{\text {th }}$ of August, 1927 & $27,084,667$ \\
\hline Increase in foreign exchange & $7,787,756$ \\
\hline Increase in Gold & 18,675 \\
\hline Purchase of $1,600,000$ dollars & $8,000,000$ \\
\hline Reserves by the $31^{\text {st }}$ of December, 1927 & $42,891,098$ \\
\hline
\end{tabular}

Source: Carbo 1978, 150.

The Ecuadorian case is very similar to others assisted by the Kemmerer Mission in Latin America, nonetheless, there is a very important difference: Kemmerer never advised the government to close private banks or to use their reserves to open the Central Bank of Ecuador. The decisions around the creation of the Caja Central de Emision y Amortización, which was a transitory institution installed until the opening of the Central Bank, was taken within a local environment of dispute between the Coast and the Highlands: politicians had one specific purpose, to restore the political and economic power in Quito.

The foundation of the Central Bank of Ecuador in 1927, apart from the foundation of institutions of banking and public spending control, is considered the breakpoint to modernization. This structuring of the fiscal system of Ecuador remains to this day. At its opening, the main function of the Central Bank was to preserve the gold standard through the use of two tools, the discount rate and the exchange rate: raising the discount rate if the money supply increased, and decreasing the discount rate if the money supply decreased; on the other hand, if the exchange rate increased, this would mean an excess of money supply, which would force the Central Bank to sell money orders abroad, and doing the opposite if the exchange rate decreased. 


\section{Public finances and the economic situation}

In 1927, Luis Napoleón Dillon published a critic chapter about the economic Ecuadorian situation in a book called The economic and financial crisis of Ecuador, which was republished by the Coordinating Ministry of Economic Policy of Ecuador in 2013. This publication tried to create a scholastic background that would present the Ecuadorian economic crisis before the revolution. Most of the book is a recollection of notes written in the newspaper El Día with the name "Cases and things Mr. Kemmerer ought to know, a brief history of an eleven-year tyranny." The title of this note had a clear argument: Ecuador was living a tyranny before the revolution, and therefore, some kind of intervention was needed.

The main purpose of this section is to evaluate whether there was an economic critical situation. The main arguments revised come from Dillon's book published in 1925 and re edited in 2013, Estrada (1922) and Riofrío (1926), having in mind the advantages of our times. The clearest advantage is the economic historical statistics for Latin America, which these authors did not have during their lifetime. Therefore, the intention of this part of the paper is not to criticize or support such arguments, but to see if there is real evidence around the idea, in the public opinion, that Ecuador was living a critical economic situation before the revolution. Moreover, it is needed to present data that these authors did not refer to, in order to have a more comprehensive context of the years before the creation of the Central Bank of Ecuador.

Before analyzing the most important arguments, it is necessary to understand the historical context: The Liberal Revolution in Ecuador started in 1895 when General Eloy Alfaro overthrew the government and was declared Commander in Chief. A few years later, some rights were proclaimed with the new constitution of 1897 , such as the abolition of the death 
penalty, freedom of worship, the citizenship for every person living in Ecuador, marriage and divorce as a civil matter, and the rejection of the influence of the Catholic Church in this civil matters. Alfaro was murdered in 1912. From 1913 until 1926, was a known period because,

The 'bankocracy' subordinated the people to the affluent and small group of shareholders who handled the few existing banks and that, given the dearth of the state by the crisis in the cocoa exports, they provided funds to governments and obviously they passed the bill asserting its influence on all decisions. (Lara 2012, 439)

The plutocratic period (1913-1925) was accused of creating a political context in which the influence of private bankers was excessive in the public decision-making. Bankers were accused of benefitting from this influence through public debt: private banks were the main source to finance the central government. In this sense, Dillon's first arguments contained statements that condemned the fiscal behavior of the governments during the first decades of the twenty-century making a clear reference to the government internal debt.

\section{Public debt}

The main arguments develop the idea that there was an uncontrollable internal public debt. The data presented by Dillon (2013), plus additional data on government expenditures, government incomes, and the public debt to banks from other sources, have been used to see a comprehensive panorama of this statements. From 1913, as shown in table 6 and figure 2, the ratio of the internal public debt (IPD) over government expenditures (GE) was always high; nonetheless, it increases substantially during the twenties, with the highest pick in 1921, registering a radio of 1.3:1. During the twenties, the internal public debt exceeded the total amount of public expenditures, which in turn shows a constant fiscal deficit.

When looking closely at the numbers, it is clear that the internal public debt was high and that it increased during the twenties, and even double the amount of previous years, nonetheless, 
this increment did not come from the public debt to banks. In fact, the ratio of public debt to banks (PDB) over the internal public debt (IPD) decreases from 0.66:1 in 1919 to $0.46: 1$ in 1924. The increment of the internal debt did not come from the private banking system. Moreover, it is ironic to see that the PDB/IPD increases when the military took over the government. The increment of internal public debt resulted from the Great War, a period in which Ecuador was obliged to acquire debt to finance the military expenditures (Rodríguez 1994).

Table 6. Internal public debt, government expenditures and incomes, 1914-1927, millions of current sucres

\begin{tabular}{lccccc}
\hline Year & $\begin{array}{c}\text { Internal public } \\
\text { debt, IPD }\end{array}$ & $\begin{array}{c}\text { Government } \\
\text { expenditures, GE }\end{array}$ & $\begin{array}{c}\text { Government } \\
\text { incomes, GI }\end{array}$ & $\begin{array}{c}\text { Public debt to } \\
\text { banks (PDB) / IPD }\end{array}$ & IPD / GE \\
\hline $\mathbf{1 9 1 3}$ & 14.2 & 22 & 20 & 0.57 & 0.65 \\
$\mathbf{1 9 1 4}$ & 15.2 & 23 & 16 & 0.65 & 0.66 \\
$\mathbf{1 9 1 5}$ & 17.1 & 21 & 21 & 0.65 & 0.82 \\
$\mathbf{1 9 1 6}$ & 18.6 & 18 & 18 & 0.64 & 1.04 \\
$\mathbf{1 9 1 7}$ & 18.8 & 18 & 19 & 0.66 & 1.05 \\
$\mathbf{1 9 1 8}$ & 20.7 & 17 & 18 & 0.59 & 1.22 \\
$\mathbf{1 9 1 9}$ & 22.6 & 14 & 18 & 0.66 & 1.62 \\
$\mathbf{1 9 2 0}$ & 25.6 & 23 & 15 & 0.60 & 1.12 \\
$\mathbf{1 9 2 1}$ & 28.5 & 22 & 21 & 0.61 & 1.30 \\
$\mathbf{1 9 2 2}$ & 32.5 & 27 & 25 & 0.63 & 1.21 \\
$\mathbf{1 9 2 3}$ & 36 & 29 & 25 & 0.48 & 1.24 \\
$\mathbf{1 9 2 4}$ & 39.8 & 35 & 31 & 0.46 & 1.14 \\
$\mathbf{1 9 2 5}$ & 49.3 & 44 & 39 & 0.67 & 1.12 \\
$\mathbf{1 9 2 6}$ & 42.4 & 19 & 65 & 0.72 & 0.96 \\
$\mathbf{1 9 2 7}$ & 19.8 & 44 & & -28 & \\
\hline
\end{tabular}


Figure 2. PDB / IPD; IPD / GE, 1913-1925, millions of current sucres

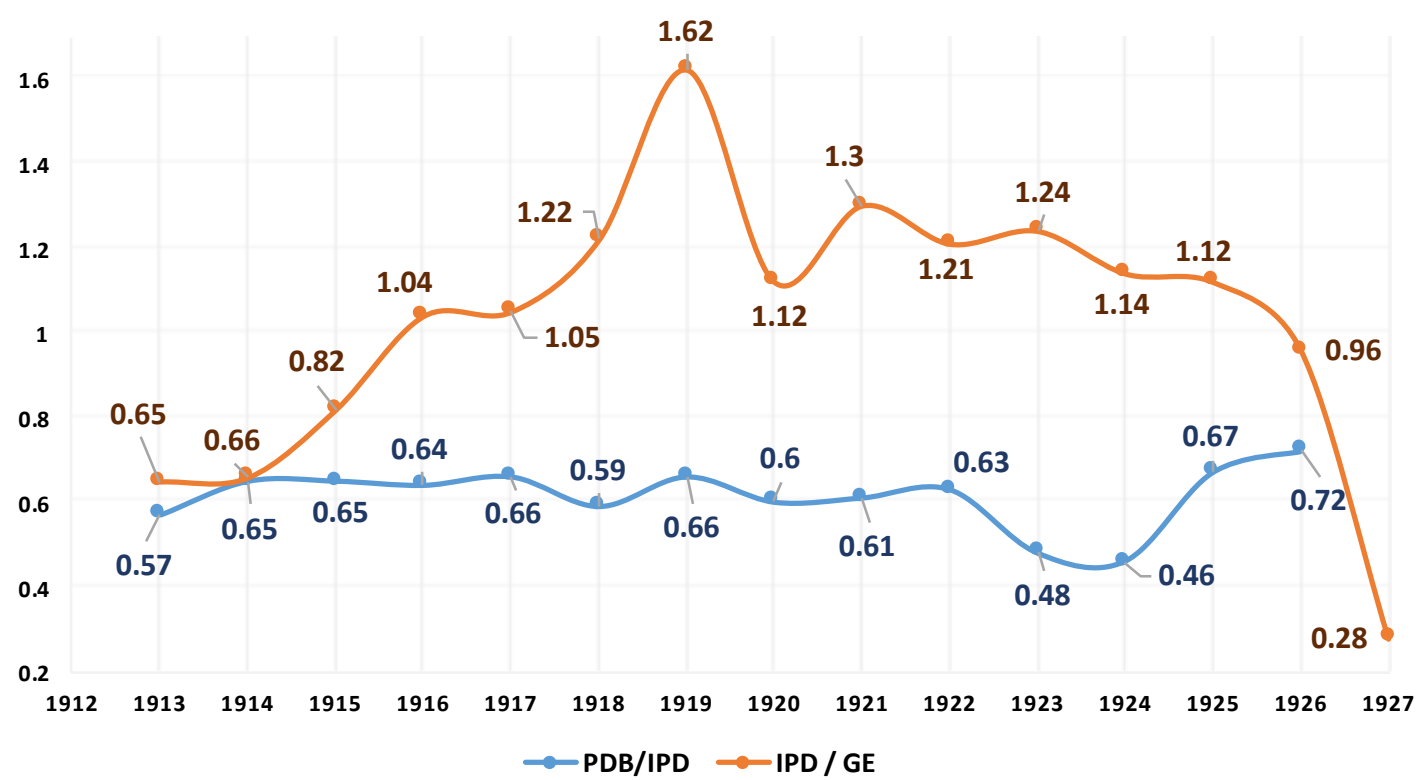

Source: Author's creation. For 1914-1925, data of internal public debt comes from Dillon 2013, 66; for 1913, IPD comes from Rodríguez 1992, 143. Data for government expenditures and incomes come from MoxLad 2016. Data for Public debt to banks comes from Rodríguez 1992, 143.

It is easy to imagine and accept the statements that portray private banks as having a major influence over governmental decisions because of the high public debt that was owed to them. Nevertheless, after the Revolución Juliana, after the closure of many private banks, and after the foundation of the Central Bank of Ecuador, the percentage of public debt to private banks increased year after year, 79.6 percent in 1931, 91.6 percent in 1934 (Rodríguez 1992, 143). The fiscal relation to banks did not change in time.

\section{External trade and government incomes}

The main productive sectors were related to three agricultural products: cocoa, coffee and ivory nuts. Cocoa exports represented 60 percent of total exports. Local families from the coast were dedicated to exploit the wild cocoa, “[...] a small group of some 20 families emerged, controlling more than 70 percent of the productive lands[...] Aspiazu (57 
properties), Puga (16 properties), Seminary (39 properties), Caamaño (23 properties), Morin (28 properties), Duran-Ballén (La Clementina), Burgos (23 properties), Mandinyá (8 properties) and Sotomayor (4 properties)" (Paz y Miño Cepeda 2011, 54).

More than 44 percent of government revenues came from customs, becoming the main source of public finances. This percentage fluctuated during the twenties, registering some high and low picks because of the crisis in the production of cocoa, the main product for exportation. As seen in table 7 and figure 3, exports grew continuously during the twenties while the ratio of cocoa/total exports reduced uninterruptedly.

The importance of cocoa exportations was decreasing because of two main reasons. First, the plagues that cocoa plantation suffered, there were two major diseases that attacked cocoa plantations, the first is known as witches' broom, and the second known as Monilia fungus, both caused the tree to quickly dry in seven-ten days. Second, the First World War affected the commercial relations between Ecuador and the European market. There were some plans to recover the plantations, which worked partially; however, cocoa exports never recovered the production and the level of exports (60 percent of total exports) registered during the first decade of the twenty-century.

While the ratio of cocoa/total exports was decreasing, other products, among which the main one was oil, were replacing cocoa. Oil exports represented less than five percent of total exports during the first decade of the twenty-century, however, its importance increased rapidly during the second decade, registering 19.6 percent of total exports in 1930 (Naranjo 2016, 76). Another export product that increased its importance was coffee. Coffee exports represented 1.8 percent of total products in 1920 , whereas in 1926 it represented 18.1 percent of total exports (Rodríguez 1992, 214). 
Table 7. Trade Balance in Ecuador, millions of current sucres

\begin{tabular}{lccccccc}
\hline Years & Total exports & $\begin{array}{c}\text { Exports } \\
\text { index }\end{array}$ & $\begin{array}{c}\text { Total } \\
\text { imports }\end{array}$ & $\begin{array}{c}\text { Imports } \\
\text { index }\end{array}$ & Balance & $\begin{array}{c}\text { Cocoa } \\
\text { Exports }\end{array}$ & $\begin{array}{c}\text { Cocoa/ total } \\
\text { exports }\end{array}$ \\
\hline $\mathbf{1 9 1 3}$ & 32.4 & 100.0 & 18.1 & 100.0 & 14.3 & 20.5 & 0.63 \\
$\mathbf{1 9 1 4}$ & 26.8 & 82.7 & 17.2 & 95.0 & 9.5 & 20.7 & 0.77 \\
$\mathbf{1 9 1 5}$ & 26.5 & 81.8 & 17.3 & 95.6 & 9.2 & 19.9 & 0.75 \\
$\mathbf{1 9 1 6}$ & 36.1 & 111.4 & 19.1 & 105.5 & 16.9 & 26.2 & 0.73 \\
$\mathbf{1 9 1 7}$ & 32.8 & 101.2 & 20.9 & 115.5 & 11.9 & 21.9 & 0.67 \\
$\mathbf{1 9 1 8}$ & 27.1 & 83.6 & 16.6 & 91.7 & 10.4 & 17.1 & 0.63 \\
$\mathbf{1 9 1 9}$ & 42.7 & 131.8 & 24.0 & 132.6 & 18.7 & 29.4 & 0.69 \\
$\mathbf{1 9 2 0}$ & 48.8 & 150.6 & 43.4 & 239.8 & 5.3 & 35.5 & 0.73 \\
$\mathbf{1 9 2 1}$ & 32.7 & 100.9 & 23.4 & 129.3 & 9.2 & 20.3 & 0.62 \\
$\mathbf{1 9 2 2}$ & 44.7 & 138.0 & 33.5 & 185.1 & 11.1 & 30.2 & 0.68 \\
$\mathbf{1 9 2 3}$ & 36.8 & 113.6 & 36.8 & 203.3 & 0.02 & 18.8 & 0.51 \\
$\mathbf{1 9 2 4}$ & 59.2 & 182.7 & 52.0 & 287.3 & 7.2 & 30.2 & 0.51 \\
$\mathbf{1 9 2 5}$ & 69.6 & 214.8 & 55.2 & 305.0 & 14.4 & 33.9 & 0.49 \\
$\mathbf{1 9 2 6}$ & 60.2 & 185.8 & 47.0 & 259.7 & 13.2 & 26.4 & 0.44 \\
$\mathbf{1 9 2 7}$ & 74.8 & 230.9 & 57.0 & 314.9 & 17.7 & 36.9 & 0.49 \\
& & & & & & & \\
\hline
\end{tabular}

Source: Author's creation. Data for exports and imports come from Banco Central del Ecuador 1940, 17. Data for cocoa exportations come from Rodriguez 1992, 223.

The trade balance of Ecuador fluctuated (table 7), from 1913 to 1927, dramatically, drawing constantly high and low peaks. In millions of sucres, the high peaks are visible in 1916 (16.9), 1919 (18.7), and 1927 (17.7), while the low peaks occurred in 1920 (5.3), and 1923 (0.02). In US dollars, the fluctuation of the trade balance is similar to the one registered in sucres. Nonetheless, the apparent recovery of the trade in sucres in 1927 does not have the same impact in US dollars: from 1926 to 1927, in millions of sucres, the balance trade moved from 13.2 to 17.7 , while, in million US Dollars, it moved from 2.5 to 3.5 , this data shows that, even 
though in nominal prices, the trade improved in one year, the exchange rate diminished the significance of the improvement. These fluctuations in the trade balance are related to the fact that Ecuadorian main product of exportation, cocoa, reduced its production because of the attack of diseases in the plantations. Furthermore, from 1913 to 1927, in million US dollars, the trade balance reduced in almost half, from 6.6 to 3.5: a real catastrophe for external trade.

Figure 3. Exports index, cocoa export/ total exports, Ecuador, 1923/1927

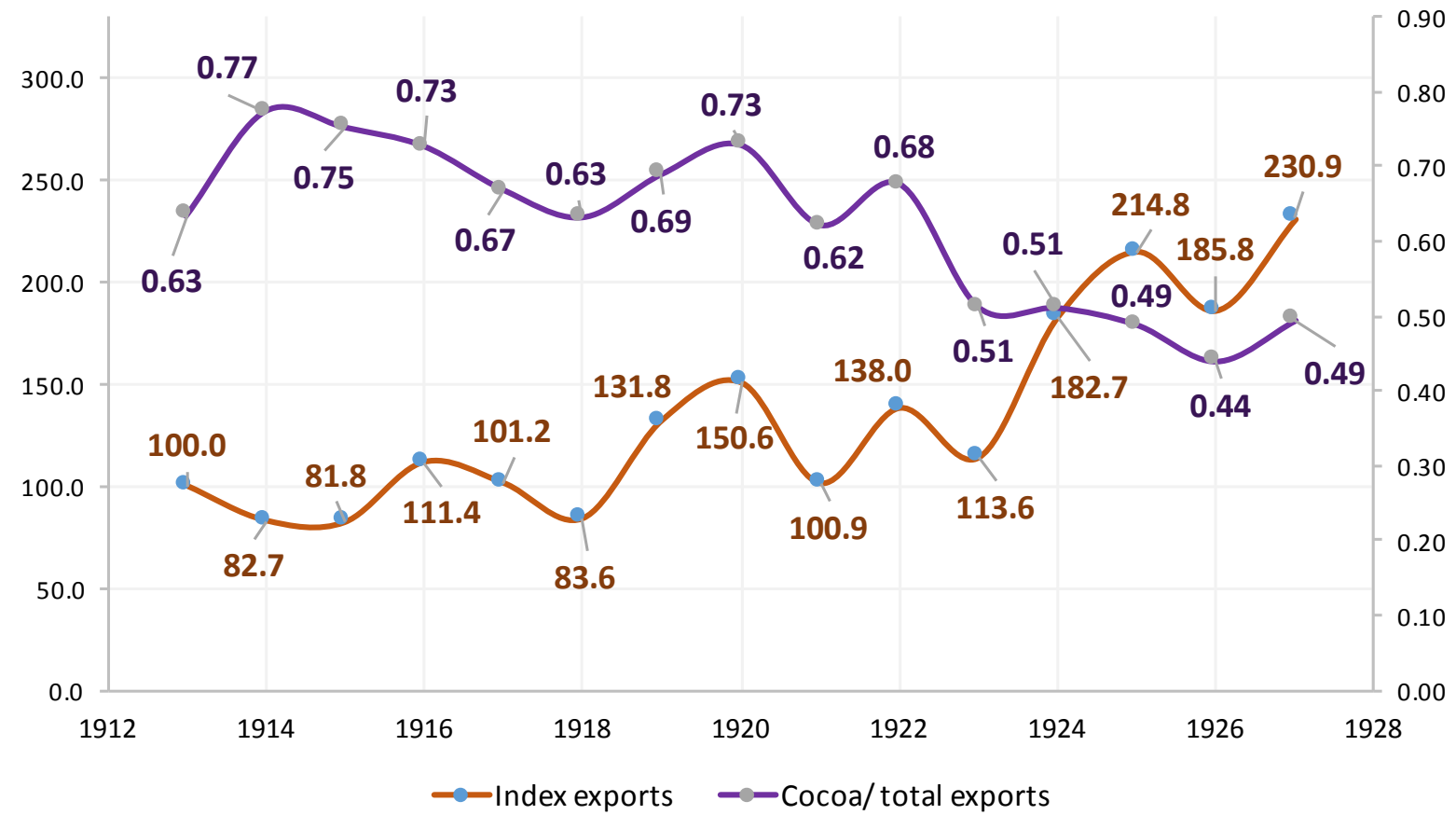

Source: Author's creation. Data for exports and imports come from Banco Central del Ecuador 1940, 17. Data for cocoa exportations come from Rodriguez 1992, 223. Secondary axis for Cocoa/ total exports.

\section{Money supply, inflation, and exchange rates}

Around the idea of crisis, another argument used was the inorganic currency supply. Before the creation of the Central Bank of Ecuador (1927), the emission of currency was in the hands of private banks, which decided the emission of currency given their own judgment, "the money supply increased from 18 to 38 million" (Dillon 2013, 97), even though Dillon does 
not mention any time period, it might be from 1917 to 1927 . This statement involves the increment of the inflation and, therefore, the decreasing of the purchasing power.

As shown in table 8, money supply increased from 1922 to 1925 in 76 percent (current prices), which would raise the inflation rates. The Great War left the region with a major devaluation of local currencies (table 10) that obliged governments to increase the monetary supply. The case of Ecuador is not separated from the region, yet, its devaluation and inflation was higher than the average of the region. It is important to notice that until 1919 the exchange rate of the region fluctuated with no major changes, but, after World War I, devaluation was a common symptom. The restriction of the monetary supply in Ecuador in 1922 was a policy to try to control the inflation rates that were raising because of the devaluation of the currency.

Table 8. Money supply, Ecuador, 1920-1927

\begin{tabular}{|c|c|c|c|c|c|}
\hline Year & Gold & Currency & Deposits & $\begin{array}{l}\text { Money supply } \\
\text { Constant prices }\end{array}$ & $\begin{array}{l}\text { Money supply } \\
\text { Current prices }\end{array}$ \\
\hline 1920 & $9,324,322.00$ & $22,455,896.00$ & $13,711,835.00$ & $36,167,731.00$ & $36,167,731.00$ \\
\hline 1922 & $8,346,240.90$ & $16,671,484.40$ & $13,697,009.30$ & $30,368,493.70$ & $34,738,519.94$ \\
\hline 1923 & $7,688,158.60$ & $24,328,490.20$ & $14,420,577.00$ & $38,749,067.30$ & $48,482,833.01$ \\
\hline 1925 & $6,669,754.50$ & $25,412,894.00$ & $15,801,331.40$ & $41,214,225.50$ & $60,609,640.02$ \\
\hline 1927 & & $22,525,412.70$ & $11,193,707.20$ & $34,125,950,2$ & $58,573,780.92$ \\
\hline
\end{tabular}


Table 9. Price index, Ecuador and Latin America, 1913-1927

\begin{tabular}{lccccc}
\hline Year & Ecuador & Colombia & Venezuela & Peru & Latin America \\
\hline $\mathbf{1 9 1 3}$ & 100 & 100 & 100 & 100 & 100 \\
$\mathbf{1 9 1 4}$ & 100 & 67 & 100 & 100 & 92 \\
$\mathbf{1 9 1 5}$ & 130 & 67 & 105 & 100 & 101 \\
$\mathbf{1 9 1 6}$ & 170 & 67 & 114 & 100 & 113 \\
$\mathbf{1 9 1 7}$ & 204 & 67 & 130 & 133 & 133 \\
$\mathbf{1 9 1 8}$ & 238 & 67 & 135 & 133 & 143 \\
$\mathbf{1 9 1 9}$ & 214 & 133 & 157 & 167 & 168 \\
$\mathbf{1 9 2 0}$ & 192 & 133 & 178 & 167 & 168 \\
$\mathbf{1 9 2 1}$ & 194 & 100 & 135 & 167 & 151 \\
$\mathbf{1 9 2 2}$ & 215 & 100 & 124 & 167 & 160 \\
$\mathbf{1 9 2 3}$ & 208 & 100 & 124 & 167 & 198 \\
$\mathbf{1 9 2 4}$ & 242 & 133 & 130 & 167 & 168 \\
$\mathbf{1 9 2 5}$ & 245 & 167 & 135 & 167 & 167 \\
$\mathbf{1 9 2 6}$ & 309 & 167 & 141 & 167 & \\
$\mathbf{1 9 2 7}$ & 300 & 167 & 135 & & 168 \\
\hline
\end{tabular}

Figure 4. Price index, Ecuador and Latin America, 1913-1927

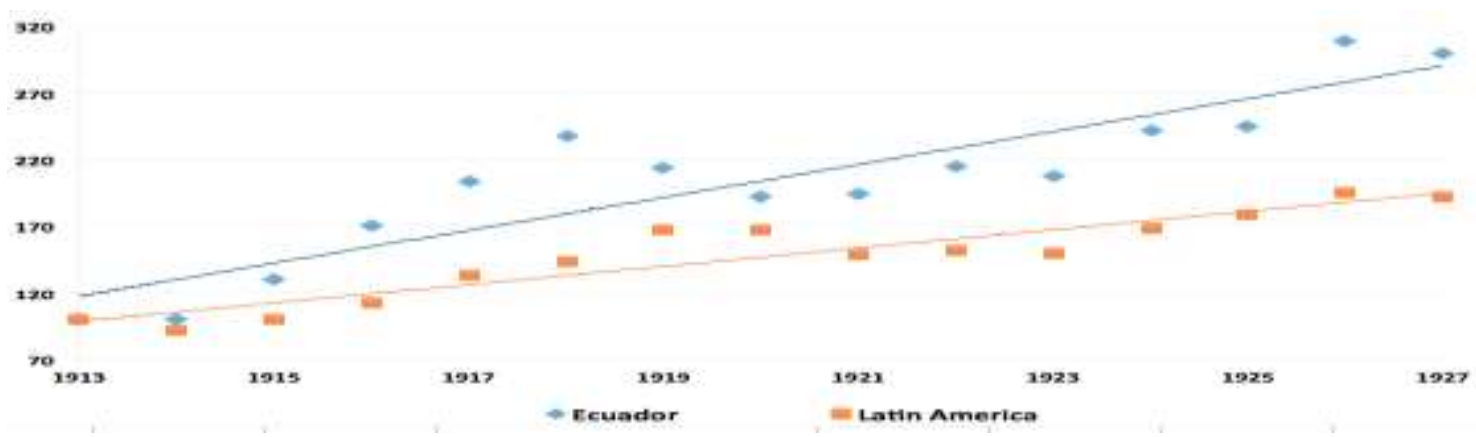

Source: Author's creation. Data for Ecuador comes from Drake 1984, 220; for the rest of countries, MoxLad 2016. Data for Latin America base year is $1970=100$; the base has been changed to 1913. Logarithmic trend lines. 
Journal of Evolutionary Studies in Business

Table 10. Exchange rate, Ecuador and Latin America, 1913-1927 (LCU/US \$)

\begin{tabular}{lccccccc}
\hline Year & Ecuador & Brazil & Bolivia & Chile & Peru & Venezuela & Latin America \\
\hline $\mathbf{1 9 1 3}$ & 2.09 & 3 & 3 & & 2 & 5 & 3.02 \\
$\mathbf{1 9 1 4}$ & 2.11 & 3 & 3 & 7 & 2 & 5 & 3.69 \\
$\mathbf{1 9 1 5}$ & 2.15 & 4 & 3 & 6 & 2 & 5 & 3.69 \\
$\mathbf{1 9 1 6}$ & 2.23 & 4 & 3 & 4 & 2 & 5 & 3.37 \\
$\mathbf{1 9 1 7}$ & 2.48 & 4 & 3 & 4 & 2 & 5 & 3.41 \\
$\mathbf{1 9 1 8}$ & 2.57 & 4 & 2 & 3 & 2 & 4 & 2.93 \\
$\mathbf{1 9 1 9}$ & 2.14 & 4 & 3 & 4 & 2 & 5 & 3.36 \\
$\mathbf{1 9 2 0}$ & 2.25 & 4 & 3 & 5 & 2 & 6 & 3.71 \\
$\mathbf{1 9 2 1}$ & 3.46 & 8 & 4 & 8 & 3 & 6 & 5.41 \\
$\mathbf{1 9 2 2}$ & 4.27 & 8 & 4 & 8 & 3 & 5 & 5.38 \\
$\mathbf{1 9 2 3}$ & 4.79 & 10 & 3 & 8 & 2 & 5 & 5.47 \\
$\mathbf{1 9 2 4}$ & 5.03 & 9 & 3 & 9 & 2 & 5 & 5.51 \\
$\mathbf{1 9 2 5}$ & 4.32 & 8 & 3 & 9 & 2 & 5 & 5.22 \\
$\mathbf{1 9 2 6}$ & 5.12 & 7 & 3 & 8 & 3 & 5 & 5.19 \\
$\mathbf{1 9 2 7}$ & 5.01 & 8 & 3 & 8 & 3 & 5 & 5.34 \\
\hline
\end{tabular}

Figure 5. Exchange rate, Ecuador and Latin America, 1913-1927, 1913=100

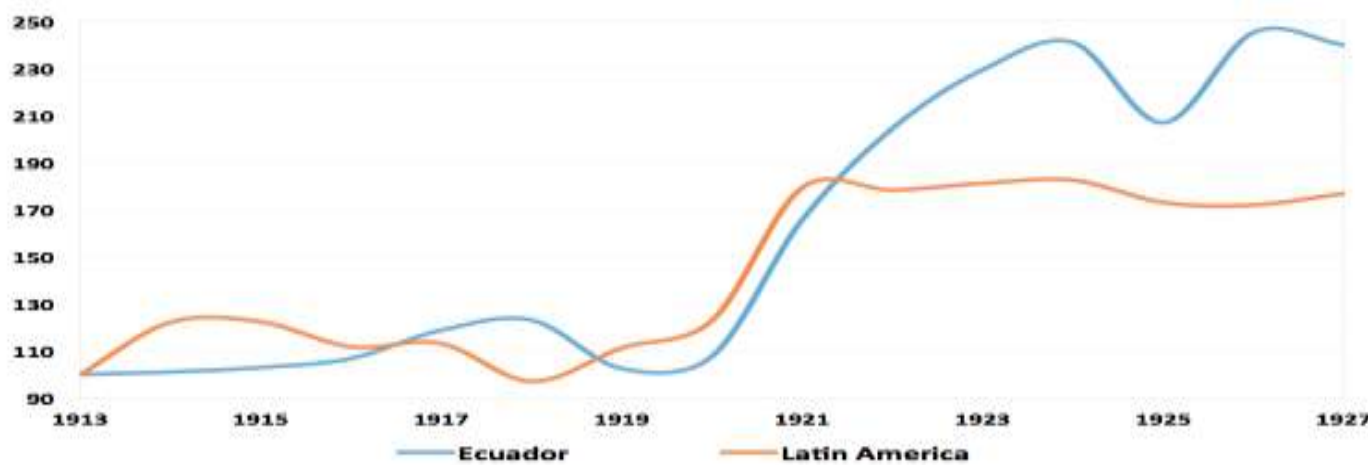

Source: Author's creation. Data for Ecuador comes from Dirección Nacional de Estadística 1944, 373; for Latin America, MoxLad 2016. 
The argument on the increasing cost of living is supported by the statistics presented in this section. The inflation rates of Ecuador show a general tendency to escalate until 1926, with two picks, in 1918 and 1926. This phenomenon is the product of the devaluation of the currency and the increment of money supply that came from private banking, responsible of the emission of currency. Ecuador is not a single case in the region, on the contrary, the region shows a similar pattern: an escalating inflation and currency devaluation.

\section{Gross Domestic Product}

Regarding the evolution of the Gross Domestic Product, from 1914 to 1927, there is a constant increase of an annual average of 3.9 percent, which is the media of the region for the same period. There is no year with a negative growth. Latin America shows a decreasing GDP in 1914 due to the beginning of the Great War, "in a very short time the entire banking and credit system and the organization of money markets were suspended, which in Latin America caused an acute liquidity crisis and financial panic in 1913-1914" (Bethell 1991, 53$54)$.

The falling of Great Britain as the international hegemon gave space for United States to become the first commercial partner in Latin America. From 1914, United States was the destiny of more than 40 percent of the total exports of the region. There was also an increasing foreign investment in strategic sectors as: mining in Mexico, railways in Ecuador, copper in Peru, bananas in Colombia and sugar in Cuba, "private investment of the United States abroad increased from 3500 million in 1915 to 6400 million in 1919" (Lewis 1938, 449).

After the Great War, the U.S. established a strong presence in the region through foreign investments and commerce. This increasing influence came along with the idea of a reduced 
role of the government and free market. Bethell (1991) affirms that the foreign investment in the region increased, from 1919 to 1928 in around 30 percent, which shows that the American presence, and its model of growing, was spread in most part of Latin America. The economic growth of the region was based on the exports until 1929, when the Great Depression collapsed the model and gave birth to a period of protectionism and industrialization.

Table 11. Gross Domestic Product, $1970=100$, in millions of local currencies

\begin{tabular}{|c|c|c|c|c|c|c|c|c|}
\hline Years & Argentina & Brazil & Ecuador & Venezuela & Peru & Colombia & Uruguay & $\begin{array}{c}\text { Latin } \\
\text { America }\end{array}$ \\
\hline 1913 & 14048 & 11689 & 2402 & 1416 & 18912 & 8239 & 142250 & 28422.3 \\
\hline 1914 & 12587 & 11434 & 2507 & 1229 & 18797 & 8552 & 118517 & 24803.3 \\
\hline 1915 & 12657 & 11946 & 2621 & 1259 & 20417 & 8947 & 112383 & 24318.6 \\
\hline 1916 & 12292 & 12295 & 2714 & 1179 & 22533 & 9408 & 116217 & 25234.0 \\
\hline 1917 & 11294 & 13145 & 2808 & 1367 & 23365 & 9794 & 128193 & 27138.0 \\
\hline 1918 & 13373 & 12878 & 2908 & 1349 & 23505 & 10338 & 135861 & 28601.7 \\
\hline 1919 & 13865 & 14577 & 3040 & 1252 & 24286 & 11197 & 153496 & 31673.3 \\
\hline 1920 & 14877 & 16015 & 3177 & 1493 & 24529 & 11962 & 133852 & 29415.0 \\
\hline 1921 & 15256 & 16349 & 3291 & 1543 & 25544 & 12651 & 140826 & 30780.0 \\
\hline 1922 & 16464 & 17476 & 3407 & 1576 & 27745 & 13507 & 161054 & 34461.3 \\
\hline 1923 & 18290 & 18479 & 3526 & 1806 & 29656 & 14369 & 169561 & 36526.7 \\
\hline 1924 & 19709 & 18467 & 3650 & 2077 & 32449 & 15186 & 185809 & 39621.0 \\
\hline 1925 & 19625 & 18541 & 3779 & 2666 & 33307 & 16005 & 178543 & 38923.7 \\
\hline 1926 & 20566 & 18938 & 3900 & 3203 & 36689 & 17533 & 194900 & 42247.0 \\
\hline 1927 & 22027 & 20313 & 4104 & 3569 & 37337 & 19112 & 222941 & 47057.6 \\
\hline
\end{tabular}

Source: MoxLad 2016. Figures are estimated with rate of growth of GDP \$PPP 1990 from Bertola and Ocampo 2010. 
Figure 6. Real GDP, Latin America, 1913-1927, 1913=100

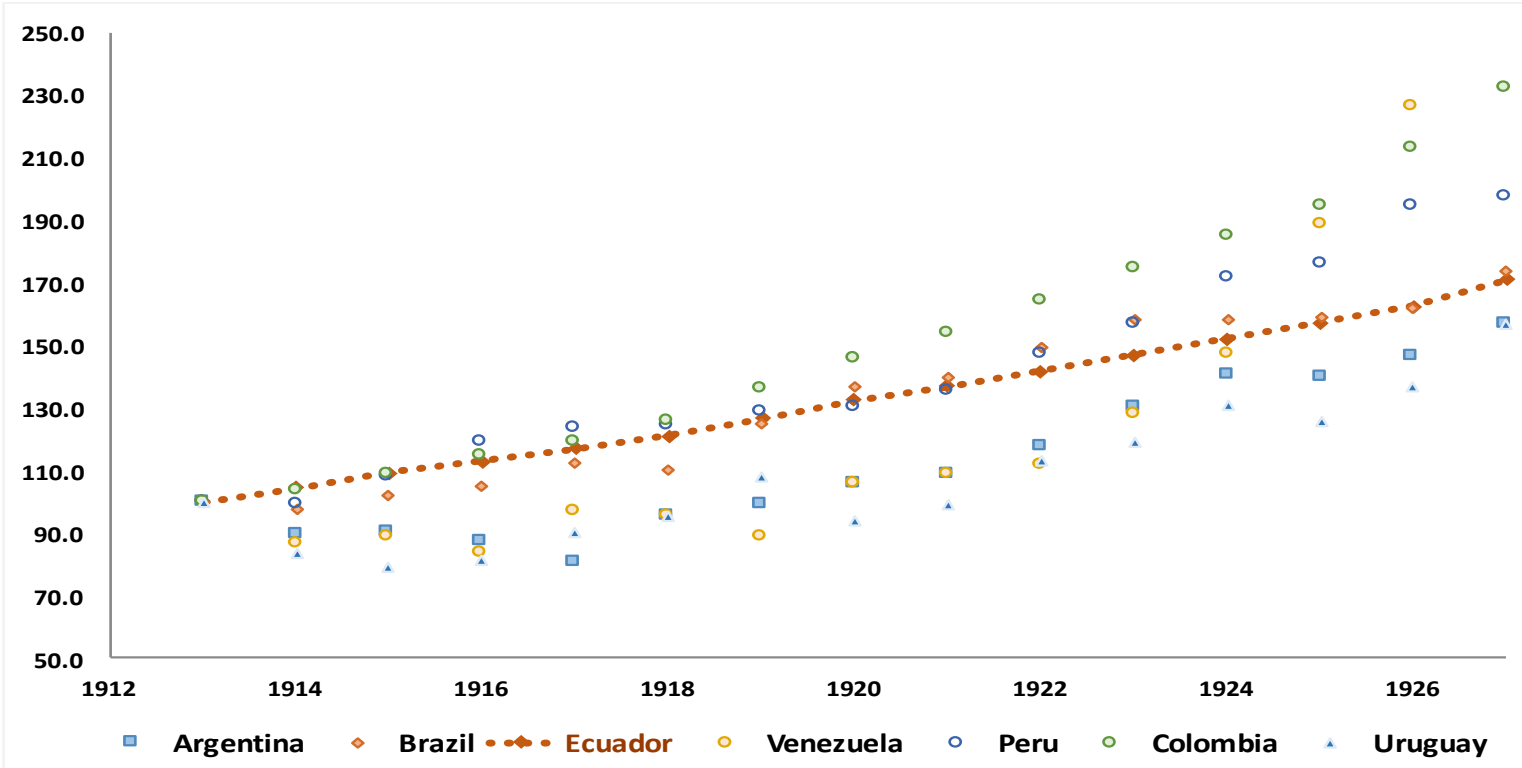

Source: MoxLad 2016. Figures are estimated with rate of growth of GDP \$PPP 1990 from Bértola and Ocampo 2010.

The case of Ecuador represents the mean of the region, the constant increase of the Gross Domestic Product shows that the economy was growing in a slow pace, with no substantial benefits. The evolution of GDP can be used to affirm that there was no contraction in the economy: Ecuadorian economy is not an outlier in the region, on the contrary, it represents the economic development of the region.

Even though there was a real crisis in the governmental finances, and there was an increasing cost of living, the economy of Ecuador was growing at the same pace of the region. On the other hand, the local economic problems presented in the inflation rates were not present in the majority of the population because one third of the population lived in rural areas and the majority of this section lived in a barter system (Naranjo 2016), the economic problems were present in the urban cities. The crisis was felt mainly in the urban centers of Quito and Guayaquil, which represented the two poles of development. Guayaquil was the center of the 
main exporting companies, which commercialized cocoa, coffee, and ivory nuts; while Quito was the center of the textile industries, whose production was consumed internally.

\section{Notes on social conflicts in Ecuador}

The sectors that felt the increasing cost of living, influenced by Russian Revolution, organized strikes in the main cities, especially in Guayaquil and Quito. Luna Tamayo (2013), citing Albornoz (1969), records some of the most important conflicts. As shown in table 12, the majority of the conflicts were registered in Quito and Guayaquil, most of the strikes were generated because of wages increase. Luna Tamayo $(2013,37)$ argues that there is an increasing tendency of workers' strikes, the majority of these strikes pursued some objectives: “[...] salary increase, employment, labor stability and better working conditions."

The most important event occurred on the $15^{\text {th }}$ of November 1922, when workers organized themselves and decreed in Guayaquil the first major general strike. Workers in Guayaquil could not remain in peace,

After the city lived a week without street lighting, due to cuts in the electric power, and without food supplies, thousands of workers began to march through the streets demanding immediate solutions to their problems and the high cost of living, paralyzing completely the commercial, industrial, social and economic activity of Guayaquil (Avilés Pino 2016)

The $15^{\text {th }}$ of November, hundreds of workers walked through the main streets of the city to gathered at Plaza del Centenario. After some fiery harangues, many protesters attacked the police, others tried to rob the warehouses located on the main street of the city, the Av. 9 de Octubre. After some hours of violence, with the help of the military, the police could regain the control of the city with a heavy toll of deaths.

Avilés Pino (2016) states that the general strike in Guayaquil had been interpreted by some leftist authors as the cornerstone of the social claims of the twenties. Avilés Pino considers 
that these writers, such as Joaquín Gallegos Lara (1946) and Óscar Enfrén Reyes (1949), created myths around the events on the $15^{\text {th }}$ of November 1922. The most famous myth tells the story that the corpses of the workers were thrown to the Guayas river to disappear any evidence of the massacre. The social claims, evident in the strikes of the twenties, gave birth to the Revolución Juliana.

Table 12. Workers strikes and social claims 1914 -1929

\begin{tabular}{|c|c|c|c|}
\hline Year & Type of workers & Place & Motive/actions \\
\hline 1914 & Railway workers & $\begin{array}{l}\text { Bahía de } \\
\text { Caráques- Chone }\end{array}$ & Payment of wages \\
\hline 1916 & Workers & Sugar mill Valdez & $\begin{array}{l}\text { Rising of wages and decreasing of } \\
\text { working hours }\end{array}$ \\
\hline 1916 & Cocoa workers & Guayaquil & Rising of wages \\
\hline 1916 & Wagon and urban car drivers & Guayaquil & $\begin{array}{l}\text { Rising of salaries and compliance of } \\
\text { Working hours }\end{array}$ \\
\hline 1916 & Railway workers & Durán & \\
\hline 1918 & Barbers & Guayaquil & Rising of wages \\
\hline 1918 & Tailors & Quito & Rising of wages \\
\hline 1919 & Typographers & Quito & Rising of wages \\
\hline 1919 & Miners & Portovelo & Rising of wages \\
\hline 1919 & Tailors & Riobamba & Rising of salaries \\
\hline 1919 & Pharmacy employees & Guayaquil & Rising of salaries \\
\hline 1921 & Native Indigenous & $\begin{array}{l}\text { Guano, } \\
\text { Paquicahuan y } \\
\text { Cubijíes }\end{array}$ & Resistance to territorial taxes \\
\hline 1922 & General strike of workers & Guayaquil & $\begin{array}{l}\text { Rising of salaries, labor stability, against } \\
\text { the critical economic conditions }\end{array}$ \\
\hline 1923 & Hacienda Leyto & Baños & Indigenous uprising \\
\hline 1923 & $\begin{array}{l}\text { Workers of the cigar factory La } \\
\text { Corona }\end{array}$ & Guayaquil & Rising of salaries \\
\hline 1924 & Rubber tappers & Amazon region & $\begin{array}{l}\text { Forty rubber tappers died at the hands of } \\
\text { Shuar warriors }\end{array}$ \\
\hline 1924 & Native Indigenous & Sicalpa & Indigenous uprising \\
\hline
\end{tabular}




\begin{tabular}{|c|c|c|c|}
\hline Year & Type of workers & Place & Motive/actions \\
\hline 1924 & Shuar Warriors & Amazon region & $\begin{array}{l}\text { Shuar warriors attack the camp of } \\
\text { Salesian missionaries }\end{array}$ \\
\hline 1924 & Communards & Illinsichi & Communards are faced with the army \\
\hline 1924 & Sawmill workers & Esmeraldas & 100 workers were fired \\
\hline 1924 & Operators of the cotton industry & Ambato & Rising of salaries \\
\hline 1924 & Police officers & Quito & $\begin{array}{l}\text { Insurgency of officers from Esmeraldas } \\
\text { in police headquarters }\end{array}$ \\
\hline 1928 & Native Indigenous & San José de Minas & Indigenous uprising \\
\hline 1928 & Native Indigenous & $\begin{array}{l}\text { Cebadas and } \\
\text { Flores }\end{array}$ & Indigenous uprising \\
\hline 1928 & Native Indigenous & Tisaleo & Armed uprising of 3,000 indigenous \\
\hline 1929 & Bank employees & Guayaquil & Reject retirement tax \\
\hline 1929 & Native Indigenous & Colta & $\begin{array}{l}\text { Six thousand Indigenous take control of } \\
\text { the haciendas }\end{array}$ \\
\hline
\end{tabular}

These examples show that the main economic concern in urban cities were the rise of salaries. This was a real economic issue, as shown previously. Nonetheless, as it was mentioned, the economic problems were not present in the majority of the population, which lived in rural areas and lived under their own conditions: country people were consumers of products that were harvested by themselves.

\section{Final remarks}

This article started with some enquiries, the first one regarding the arguments behind the two main readings of the Revolución Juliana: are they complementary or are they opposed to each other? The two readings of this event raise a broader debate about how some historical events in Ecuador have been written: is it possible to settle a line that divides the writers' political ideologies with the actual facts? How much of what has been written has to be doubted or expanded? 
Having in consideration that the first reading of the Revolution Juliana emphasizes the patriotic feelings of the military officers, while the second reading emphasizes the personal motivation of Luis Napoleón Dillon, it can be affirmed that both readings are complementary. In fact, this article proposes a short version that joins both perspectives: the young military officers had genuine motives as they were young and idealist, but it is also difficult to deny the personal motivation of Dillon, which were intertwined with some regional antagonism between the Coast and the Highlands.

The second question refers to the arguments that affirm that Ecuador was living within a critical economic situation. On the one hand, from 1913 to 1927, the Ecuadorian economy grew at a rate of 3.9 percent. On the other hand, the inflation in Ecuador was the highest in the region: the constant increasing of the cost of living was enough to create a social environment of a critical economic situation. Furthermore, the public finances were unbalanced due to public debt, which increased constantly during the twenties. Nonetheless, this increase did not come from the public debt to banks, but it was the result of the Great War, a period in which Ecuador was obliged to acquire debt to finance the military expenditures.

Was Ecuador living within a critical economic situation? The fluctuation in prices had diminished the purchasing power in urban areas, which, in turn, created an increasing social perception of a critical economic situation. This perception was more notorious in the industries related to the exports of cocoa: the plantation diseases affected greatly the production of cocoa, which represented 60 percent of total exports. However, the economic crisis was not an important element in rural areas, where people lived in a barter system. People in rural areas represented one third of the total population. 
Was Ecuadorian economy an isolated case or was part of a trend in the region? Ecuador was not an isolated case in Latin America, in fact, the region was going through the same issues: increasing public expenditure due to the effects of the Great War; increasing cost of living; increasing American investment; and, a slow economic growth reflected in the evolution of the GDP.

Finally, it could be argued that the Kemmerer Mission was an essential tool to spread the influence of the United States in Latin America. However, the Mission did not visit countries to impose policies or the foundation of institutions, rather the Mission visited each country after the invitation of the local government. In this sense, it is important to consider that E.W. Kemmerer never advised the Ecuadorian government to close private banks or to use their reserves to open the Central Bank of Ecuador. This decision was taken by local politicians, and it happened before the Mission's arrival.

\section{References}

Albornoz, Osvaldo. 1969. Del crimen de El Ejido a la revolución del 9 de julio de 1925. Guayaquil: Editorial Claridad.

Administración del Sr. Dr. Dn. Isidro Ayora, P. P. 1926. Transacción Gobierno Banco Comercial y Agrícola. (N. 179), Year I. Quito, Ecuador. November 9.

Almeida, Rebeca. 1994. Kemmerer en el Ecuador. Quito, Ecuador: FLACSO, Sede Ecuador.

Arosemena, Guillermo. 2002. La Revolución Juliana: Evento Ignominioso en la Historia de Guayaquil. Guayaquil, Ecuador: Archivos Históricos del Guayas.

Avilés Pino, Efrén. 2016. "Enciclopedia del Ecuador." Revolución del 15 de Noviembre de 1922. 2016. Accessed January 05, 2017. http://www.enciclopediadelecuador.com/historia-delecuador/revolucion-del-15-de-noviembre-de-1922/.

Ayora, Isidro. 1926. "Contrato Transacción Banco Comercial y Agrícola." Executive Decree. N. 25. Quito, May 3.

Banco Central de Ecuador. 1929. "Boletín Mensual." no. 26. Quito, November.

Banco Central del Ecuador. 1940. "Boletín Mensual." year XIII, 50-151. Quito, January-February. 
Basadre Grohmann, Jorge. 2010. "La misión Kemmerer y su importancia para el Banco Central." Revista Moneda 132: 5-23.

Bértola, Luis, and José Antonio Ocampo. 2010. Desarrollo, vaivenes y desigualdad: Una historia económica de América Latina desde la independencia. Madrid: SEGIB

Bethell, Luis. 1991. Historia de América Latina. América Latina: economía y sociedad, c. 1870-1930. Barcelona, España: Editorial Crítica.

Brian News Service. 1942. Edwin W. Kemmerer. Washington: Library of Congress Prints and Photographs Division.

Carbo, Luis Alberto. 1978. Historia Monetaria y Cambiaria del Ecuador. Quito: Banco Central del Ecuador.

Coral, Hector. 1995. Isidro Ayora. Quito: abrapalabra.

Carrasco, Camilo. 2009. Banco Central de Chile 1925-1964, una historia institucional (Vol. 14). Santiago, Chile: Banco Central de Chile.

Decreto Ejecutivo. 1926. "Executive Decree N. 476." Vol. tomo 2. Quito, October 20.

Dillon, Luis Napoleón. 2013. La Crisis Económico Financiera del Ecuador. Re-edition of original publication of 1925. Quito: Ministerio Coordinador de la Política Económica.

Dirección Nacional de Estadística. 1944. Ecuador en Cifras 1938-1942. Quito, Ecuador: Imprenta del Ministerio de Hacienda.

Drake, Paul. 1984. "La Misión Kemmerer en el Ecuador: revolución y regionalismo." Revista del Banco Central del Ecuador VII, 9, May.

Drake, Paul. 1995. Kemmerer en los Andes: la misión kemmerer, 1923-1933. Quito, Ecuador: Banco Central del Ecuador.

Efrén Reyes, Oscar. 1949. Breve historia general del Ecuador. Quito: Tall. Gráf. Nacionales.

El Abanderado. 1924. Year 01, no. 04. December.

El Comercio. 1927. "El Banco Central de Chile”. Quito, February 4.

El Día. 1925. "Para la transformación política: el Ministro de Gobierno comunicó oportunamente al Sr. Dr. Córdova los peligros de la situación." Quito, July 26.

El Telégrafo. 1925. "El Ejército a la Nación." Guayaquil, July 11.

Estrada, Victor Emilio. 1922. Ensayo sobre la balanza económica del Ecuador. Guayaquil: Tipografía de Julio T. Foyain.

Gallegos Lara, Joaquín. 1946. Las cruces sobre el agua. Guayaquil.

Gozzi, Eugenia, and Ricardo Tappatá. 2010. "Primera iniciativa de reforma financiera profunda en América Latina La Misión Kemmerer." Fitproper. Accessed January 6, 2017. http://www.fitproper.com/documentos/propios/Mision_Kemmerer.pdf 
Hegel, Georg Wilhelm Friedrich. 2001. The Philosophy of History. Ontario: Batoche Books.

Jácome, Luis I. 2015. "Central Banking in Latin America: From the Gold Standard to the Golden

Years." International Monetary Fund-IMF Working Paper 15-60, March.

Kemmerer, Edwin. 1922. The ABC of the Federal Reserve System. Londrés, Ecuador: Oxford University Press.

Kemmerer, Donald. 1993. Princeton's "Money Doctor": Professor E.W. Kemmerer and the Gold Standard. Edited by Princeton University Library. Vol. LV. 1 vols. Princeton: Princeton University Library.

La Antorcha. 1924. Year 01, no. 01. November.

Lara, Jorge Salvador. 2012. Breve historia contemporánea del Ecuador. México, D.F.: Fondo de Cultura Económica.

Lewis, Cleona. 1938. America's stake in International investmen. Washington: Brookings Institution, Institute of Economics.

Luna Tamayo, Milton. 2013. "Regiones, clases y enfrentamientos sociales en los 20." In Crisis y cambios de la economía ecuatoriana en los años 20, by Carlos Marchán, 233-257. Quito: Ministerio Coordinador de la Política Económica.

Marchán, Carlos. 2013. Crisis y cambios de la economía ecuatoriana en los años veinte. Quito, Ecuador: Ministerio Coordinador de la Política Económica.

Molina Calderón, José. 2007. Guatemala: un siglo de seis lustros de banca, bancos y banqueros (1877-2007). Ciudad de Guatemala, Guatemala: Kan sasana Printer.

Morillo Batlle, Jaime. 1996. Economía monetaria del Ecuador. Quito, Ecuador: Imprenta Mariscal.

MoxLad. 2016. Base de Datos de Historia Económica de América Latina Montevideo-Oxford. http://moxlad-staging.herokuapp.com/home/es\#

Naranjo, Cristian. 2016. "La Gran Depresión en Ecuador, 1927-1937. Salarios y precios." PhD diss., Universidad Autónoma de Barcelona.

Paz y Miño Cepeda, Juan. 2002. La Revolución Juliana Nación, Ejército y Bancocracia. Quito: Abya Yala.

Paz y Miño Cepeda, Juan. 2011. "La época cacaotera en Ecuador." In El ferrocarril de Alfaro. El sueño de la integración, by Sonia Fernández Rueda, 51-61. Quito: Tehis-Corporación Editora Nacional.

Pazmiño, B., and Ignacio, C. 1929. "Empleados del Banco Central del Ecuador, Quito.” Archivo Histórico del Guayas. Quito: Ministerio de Cultura y Patrimonio.

Pérez Ramírez, Gustavo. 2014. La Revolución Juliana y sus Jóvenes Líderes Olvidados. Quito: Academia Nacional de Historia. 


\section{Journal of Evolutionary Studies in Business}

Phelps, Clyde W. 1927. The foreign expansion of American banks. New York: Ronald Press Co.

Poster, Mark. 1982. "Foucault and History." Social Research (Modern Masters) 49, 1: 116-142.

Registro Oficial N. 432. 1927. Year II. Quito, Ecuador. September 8.

Riofrío, Eduardo. 1926. El problema monetario y el problema fiscal en el Ecuador. Quito: Anales de la Universidad Central.

Rodriguez, Linda. 1992. Las Finanzas en el Ecuador. Quito: Banco Central del Ecuador.

Rodríguez, Linda. 1994. Rank and privilege. The military and society in Latin America. Oxford: SR Books.

Santos Molano, Enrique. 2005. La misión Kemmerer. Revista Credencial Historia 184.

Thorp, Rosemary. 1992. "América Latina y la economía internacional desde la Primera Guerra Mundial hasta la Depresión mundial." In América Latina economía y sociedad: 1870-1930, by Leslie Bethell, 50-71. Barcelona: Editorial Crítica.

This is an Open Access article distributed under the terms of the Creative Commons Attribution-Non-Commercial-No Derivatives License (http://creativecommons.org/licenses/by-nc-nd/4.0/), which permits non-comercial re-use and distribution, provided the original work is properly cited, and is not altered or transformed in any way. 